\title{
norden
}

Nordic Council of Ministers

Ved Stranden 18

DK-1061 Copenhagen K

www.norden.org

NORDISKE ARBEJDSPAPIRER

NORDIC WORKING PAPERS

\section{The Nordic Master Programme}

From pilot project to Nordic brand

NA2013:909

http://dx.doi.org/10.6027/NA2013-909

This working paper has been published with financial support from the Nordic Council of Ministers. However, the contents of this working paper do not necessarily reflect the views, policies or recommendations of the Nordic Council of Ministers. 


\section{Report \\ The Nordic Master Programme \\ - from pilot project to Nordic brand}

The Nordic Master Working Committee 


\section{Contents}

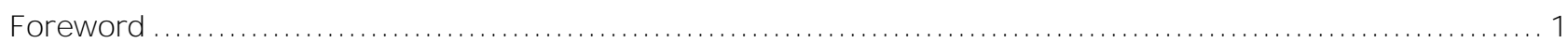

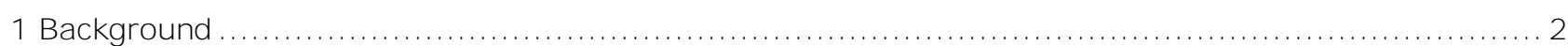

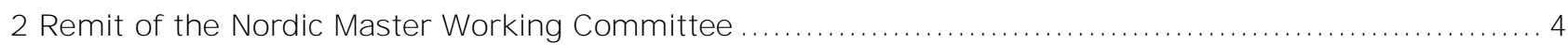

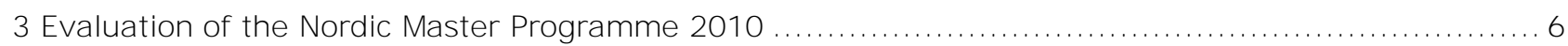

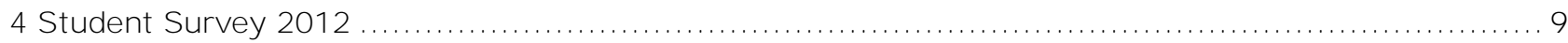

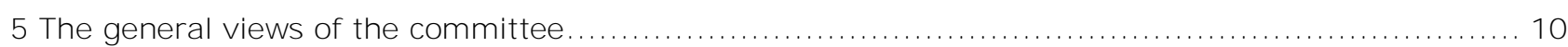

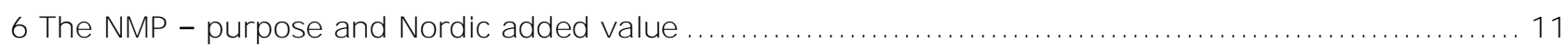

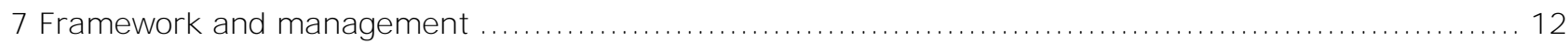

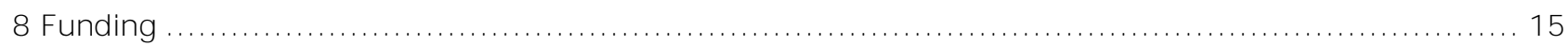

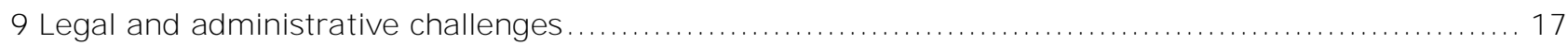

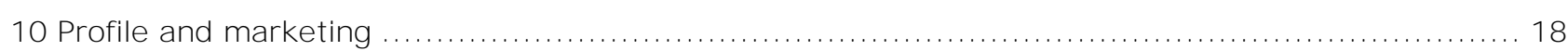

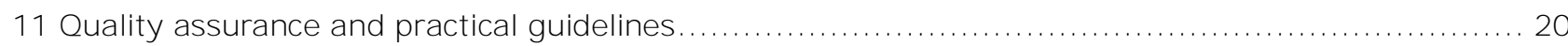

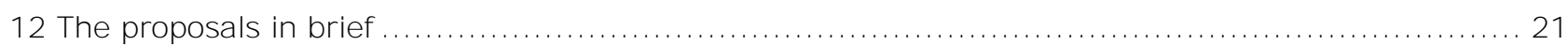

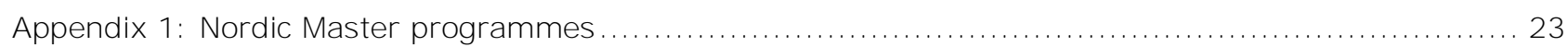

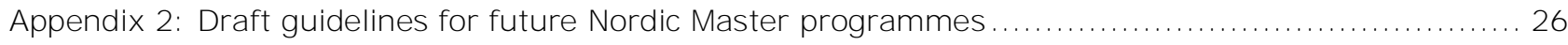

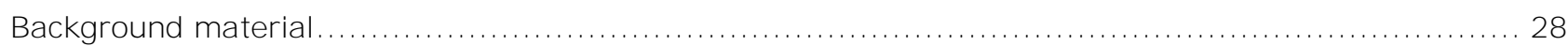




\section{Foreword}

As part of the globalisation project initiated by the Nordic prime ministers in 2007, the Nordic Council of Ministers set up the Nordic Master Programme (NMP). To date there have been four calls to tender, the most recent in 2012 .

\section{The NMP was set up to:}

- encourage Nordic higher education institutions to work more closely together more often by developing joint study programmes

- help make Nordic universities and high quality HE programmes more visible in the world at large

- draw attention to areas in which the Nordic education systems and regulatory frameworks throw up obstacles to cross-border freedom of movement, and to evaluate whether these obstacles can be removed.

Oxford Research A/S conducted an evaluation of NMP in 2010. It was generally positive but did highlight certain challenges faced. As a result, the Advisory Group for Nordic Co-operation on Higher Education (HÖGUT), under the Nordic Council of Ministers for Education and Research (MR-U), called for a more detailed follow-up evaluation, one that would identify possible future options and include a student perspective, neither of which were part of the 2010 exercise.

The Nordic Master Working Committee has held meetings and seminars with NMP stakeholders, and conducted several studies to enhance knowledge of the programme. It is against this background that the committee submits its report and proposals for the future of the NMP.

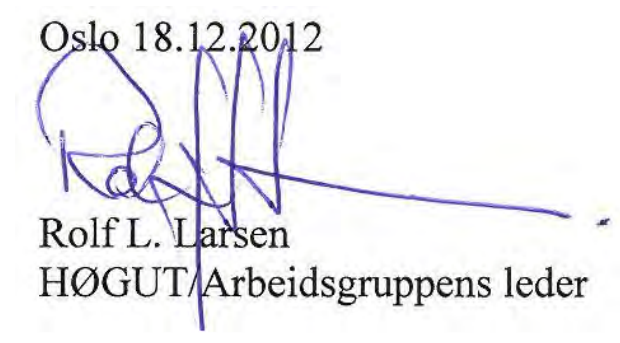




\section{Background}

In June 2007, the Nordic prime ministers issued a joint declaration calling on the Nordic Region to revamp its approach to globalisation and to strive for a more knowledgeable, visible and prosperous Region. In the period 2007-2012, this work has revolved around a social model that has as its main objectives the general welfare of the citizens of the Region, the competitiveness of business and industry, jobs, growth, culture and sustainable development. A total of 14 specific initiatives have emerged, one of which concerns promoting higher education (HE). This has included two relatively large globalisation programmes for which the Nordic Council of Ministers (NMR) has been responsible - the Nordic Knowledge Triangle Network and the Nordic Master Programme (NMP). The NMP has proved to be a successful experiment and the political will exists to continue it in a more permanent form. The Nordic Council of Ministers' Secretariat (NMRS) and the Advisory Group for Nordic Co-operation on Higher Education (HÖGUT) have set up a working committee to draw up proposals concerning the future of the NMP.

The Council of Ministers' objectives for programmes run under the auspices of the NMP are:

- to stimulate co-operation between higher education institutions and other relevant stakeholders, and to strengthen the Nordic Region as a region

- to enhance the visibility of Nordic higher education institutions in international arenas and disseminate good practice

- to develop new models for Nordic co-operation in the education sector

- to develop new areas for academic study

- to generate specialised knowledge and competences in areas where they are needed

- to stimulate and support the development of more joint Master's programmes.

Four calls for funding applications have been made for the programme - in 2007, 2009, 2010 and 2012. So far, 16 have been approved and some 350 students have commenced studies on NMP programmes. A list of these programmes is attached in Appendix 1.

The HE institutions submitting applications must comply with two main sets of criteria - formal and educational.

Formal criteria:

- Consortia must include a minimum of three educational institutions

- Funding can be applied for by institutions from the five Nordic states and from the Faroe Islands, Greenland and Åland

- Institutions must submit applications jointly as a consortium

- The same consortium that receives the funds must run the study programme

- The consortium designates a lead institution, which assumes the principal responsibility for the co-ordination of the programme.

Educational criteria:

- Each programme must amount to a total of 120 ECTS credits

- Each participating institution must provide courses amounting to a minimum of 20 ECTS credits

- The programme must culminate in the awarding of a joint diploma, two diplomas or multiple national diplomas

- The programme must be accredited in all of the participating countries.

In addition to these criteria, each call for tenders has highlighted specific priorities. In 2010, smaller educational institutions were prioritised. In previous calls to tender, it was a prerequisite that all of the participating universities also had to provide graduate training in the 
same subject as the programme. However, this was reduced to just one of the institutions in the most recent round. 


\section{Remit of the Nordic Master Working Committee}

The Nordic Council of Ministers (NMR) and the Advisory Group for Nordic Co-operation on Higher Education (HÖGUT) appointed a working committee to draw up proposals for the future of the Nordic Master Programme (NMP). Its remit was to document experiences and stakeholder input to date and, on this basis, outline how the programme might be consolidated in the longer term. The committee was also mandated to make direct proposals of its own as to whether the NMP should continue and what form it should take if it did.

The committee was asked to answer the following questions:

- How do we make the Nordic added value clearer?

- Where does the programme stand in relation to

- Nordplus?

- NordForsk?

- Erasmus Mundus?

- How can greater attention be paid to the student perspective in the development work?

- What obstacles hinder cross-border student mobility and how should these be addressed?

- How can we improve the practical implementation of the NMP:

o during the calls for tenders?

- during the start-up phase of a programme?

- What is the best long-term funding mechanism for the NMP?

- How can we improve the marketing and profile of the NMP as a brand?

- Any other questions that might arise during the process.

The committee carried out its work from 1 January until 31 October 2012. It consisted of the following individuals:

- Rolf Larsen, HÖGUT, Norway, chairperson

- Karin-Elin Berg, the Norwegian Presidency of NMR, Ministry of Education and Research

- Gudmundur R. Jónsson, HÖGUT

- Ulla-Maija Forsberg, Prorector, University of Helsinki, the Association of Nordic University Rectors' Conferences (NUS)

- Kerstin Sahlin, former Prorector, Uppsala University, NUS

- Harry Zilliacus, Senior Advisor, NordForsk (succeeded Mikael Andersson, NordForsk)

- Kai Koivumäki and Monika Mörtberg Backlund, NMRS, acted as secretaries.

Other stakeholders consulted included:

- NMP consortia

- NMP students

- The Norwegian Centre for International Co-operation in Education (SIU)

- The ENIC/NARIC Network

- The Student Support Network

- Nordplus.

The committee also commissioned a study into the obstacles to cross-border mobility identified by the NMP. This was conducted by the Nordic Institute for Studies in Innovation, Research and Education ( NIFU) in Norway. ${ }^{1}$

\footnotetext{
${ }^{1}$ Nordic Master Programme - Legal, financial, institutional and practical barriers. Nordic Institute for Studies in Innovation, Research and Education (NIFU). NIFU Report 40/2012, Oslo, Norway.

http://www. norden.org/da/publikationer/publikationer/2013-908
} 
Another study to which the committee was able to refer is "Tuition Fees for International Students - Nordic Practice" by Oxford Research. ${ }^{2}$

As well as convening meetings and hearings, the committee also wanted to learn more about students' and programme co-ordinators' experiences of the NMP. Insufficient attention had been paid to the student perspective in Evaluation of the Nordic Master Programme $2010^{3}$ - for the relatively simple reason that few students had been recruited at that stage - so a student survey was conducted in spring 2012, consisting of an online questionnaire ${ }^{4}$ and interviews with current and former students. ${ }^{5}$

\footnotetext{
${ }^{2}$ Tuiton Fees for International Students - Nordic Practice. Oxford Research, December 2012. http://www. norden.org/en/publications/publikationer/2013-516

${ }^{3}$ Evaluation of Nordic Master Programme (in Danish). Oxford Research, January 2010.

http://www. norden.org/da/nordisk-ministerraad/ministerraad/nordisk-ministerraad-for-uddannelse-og-forskning-mru/raadgivningsgrupper/raadgivningsgruppen-for-nordisk-samarbejde-inden-for-hoejere-uddannelse-hoegut/nordicmaster-program/evaluering-af-nordic-master-programme/

${ }^{4}$ Student Survey of the Nordic Master Programme 2012. Oxford Research, August 2012.

http://www. norden.org/da/publikationer/publikationer/2013-903

${ }^{5}$ Interviews with students on the Nordic Master Programme. Nordic Council of Ministers' Secretariat, project coordinator Anniina Pirttimaa, September 2012.

http://www. norden.org/da/publikationer/publikationer/2013-901
} 


\section{Evaluation of the Nordic Master Programme 2010}

Oxford Research A/S conducted the first evaluation of the pilot project in $2010 .{ }^{6}$ It concluded that the key overarching objectives of the NMP had been achieved, and that, although some of the secondary objectives had not yet been achieved in full, it was important to continue the programme.

The evaluation looked at each of the key objectives and quantified the extent to which they had been achieved:

i. To stimulate co-operation between higher education institutions and other relevant stakeholders, and to strengthen the Nordic Region as a region.

This objective had largely been met. The evaluation recommended even closer co-operation and that other stakeholders, e.g. business and industry, be encouraged to get involved in the NMP.

ii. To enhance the visibility of Nordic higher education institutions in international arenas and disseminate good practice.

This objective had not yet been fully achieved, and a need was identified for more systematic profiling of the programme. The evaluation recommended building the NMP brand.

iii. To develop new models for Nordic co-operation in the education sector.

The evaluation identified relatively large variation between individual NMP programmes. Innovation had played a more central role in some programmes than in others. The evaluation recommended that innovation and originality should shape programmes.

iv. To develop new areas for academic study.

This objective is partially linked to the one of creating new models for educational cooperation. The evaluation revealed major variation between programmes - some had been innovative, created whole new Master's programmes and found new models for working together, while others had predominantly built on existing practice. The evaluation recommended that stricter demands be imposed on programmes' educational ambitions.

v. To generate specialised knowledge and competences in areas where they are needed.

The evaluation concluded that more work needed to be done on this objective. Although many of the programmes appeared to serve as a good springboard for a research career, it was too early to say how the NMP graduates' careers would work out. This was compounded by the fact that so few students had sat exams at that point in time. The evaluation recommended that consideration be given to whether programmes should be based on demand and need, or whether other criteria should be more prominent.

vi. To stimulate and support the development of more joint Master's programmes.

\footnotetext{
${ }^{6}$ Evaluation of Nordic Master Programme (in Danish). Oxford Research, January 2010.

http://www.norden.org/da/nordisk-ministerraad/ministerraad/nordisk-ministerraad-for-uddannelse-og-forskning-mru/raadgivningsgrupper/raadgivningsgruppen-for-nordisk-samarbejde-inden-for-hoejere-uddannelse-hoegut/nordicmaster-program/evaluering-af-nordic-master-programme/
} 
Much progress has been made towards achieving this objective. The evaluation showed that the NMP had helped to support and develop existing Master's programmes in the Nordic Region, e.g. adding a cross-border mobility dimension, and had also facilitated the development of completely new programmes, both within individual disciplines and between multiple disciplines. However, the evaluation also identified various legal or administrative challenges to co-operation between the countries. Oxford Research considered that a particularly fruitful result of the pilot project had been identifying and drawing attention to the different types of barriers to cross-border mobility in terms of legislation, administrative practices and university structures.

Overall, the evaluation concluded that the NMP had been a successful pilot project. It had improved co-operation between countries in the HE sector, helped to draw attention to the internationalisation of study programmes and identified the challenges thrown up by current structures. It also enjoyed a great deal of support from the participating parties - especially the students.

Scope for improvement was, however, identified at the following levels:

Consortium level

$>$ Involve administrative personnel more closely at the initial stages

$>$ Involve the management of HE institutions more closely.

Programme level

$>$ Fund fewer NMP programmes

Dncourage greater innovation and creativity in the programmes

$>$ Promote financial stability, flexibility and "lightness"

$>$ Place greater emphasis on the "Nordic dimension" in the development of new areas of research

$>$ Draw up instructions and guidelines for administrators and students

$>$ Enhance "Nordic Master" as a brand.

Nordic level

> Amend legislation and remove legal obstacles to mobility.

Stakeholders have subsequently commented on the evaluation.

The Norwegian Centre for International Co-operation in Education (SIU), which has acted as the main NMP administrator since the 2009 call for tenders, pointed out that the evaluation mainly covered programmes approved in 2007 and 2009, because the 2010 programmes had not yet properly started at the time the evaluation was conducted. The evaluation paid insufficient attention to the financial framework conditions for the calls to tender - the NMR managed the initial call itself and the resources that NMRS had at its disposal were not directly comparable with those available to SIU. SIU identified several points in the tendering process that could be improved, e.g. greater clarity in the documentation, longer deadlines for applications, greater commitment by management in the HE institutions, the opportunity to use project funding for the implementation of the programme, etc.

The Association of Nordic University Rectors' Conferences (NUS) was in favour of the programme continuing but suggested changes to certain aspects, e.g. allowing grants to be used both for managing the initial phase of the programme and for mobility scholarships for students. NUS proposed that the Council of Ministers should take on the task of removing barriers to freedom of movement. Such barriers are not unique to NMP, so it would be useful to relate experiences to those of other similar programmes, e.g. Erasmus Mundus. NUS also called for better marketing of NMP programmes, for fewer of them, for the Nordic added value 
to be made more obvious and for administrators, researchers and university management all to be involved in the development of the NMP.

One important outcome of the evaluation has been to identify challenges and obstacles to cross-border freedom of movement, problems that stem from incompatible administrative structures, different approaches to tuition fees in different countries, the need to harmonise rules for joint and dual degrees ${ }^{7}$ and the need to simplify accreditation. As a project, NMP has provided a tangible way in which to draw attention to areas of the HE sector in which it is worth considering, from a political perspective, whether further work should be done to encourage closer Nordic co-operation. 


\section{Student Survey 2012}

The Nordic Council of Ministers commissioned Oxford Research to conduct an NMP student survey in spring 2012. The survey consisted of an online questionnaire filled in between May and J une. ${ }^{8}$ During the same time period, fourteen students were interviewed by phone in order to obtain an in-depth, qualitative understanding of students' opinions of the NMP programmes. ${ }^{9}$ Students were also invited to discuss the results and provide practical suggestions for improvements to NMP programmes at four workshops in September and October. Approximately 40 current and former NMP students attended the workshops, i.e. approx. $11 \%$ of the total number.

Generally speaking, NMP students do not constitute a homogeneous group: approximately $40 \%$ are from the Nordic Region, about 20\% from elsewhere in Europe, and $40 \%$ are nonEuropean. What they do have in common is an extremely high level of ambition and a desire to specialise further in their field, which is reflected in the fact that up to $60 \%$ of them plan to progress to postgraduate studies after the NMP.

The survey served as a useful tool to identify both strengths and weaknesses of the NMP. Results indicate that students are happy with the academic content of their programmes. However, some programmes have not lived up to expectations and specific criticisms include poor administration and a lack of information. The lack of a readily identifiable programme coordinator has been particularly problematic, e.g. some students did not receive enough information about the various options open to them. Confusion about diplomas and tuition fees was identified as a problem. The students also made it clear that they would like to see closer connections with the worlds of work and research that they will encounter after graduating from NMP programmes.

The students confirmed many points that had been raised previously in other contexts - NMP programmes have the potential to serve as an attractive, innovative and holistic form of study, but they need greater support. The survey also clearly shows that the NMP is not a uniform product, and that the programmes have been implemented in very different ways - mobility varies from short stays supplemented by Web-based courses to several months spent in different countries. The recruitment process and student support also vary, which means that the programmes vary greatly in their scope and in their student services. As a result, the students' perceptions of the quality of their programmes, and the extent to which they identify themselves as NMP students, vary considerably from programme to programme. A need for more uniform quality assurance, better support services and a greater sense of being part of an NMP community clearly emerges from the discussions with students.

The study also came up with a range of specific suggestions for support materials for students and programme co-ordinators. NMRS has started working with the co-ordinators on a joint handbook for the planning and implementation of NMP programmes.

\footnotetext{
${ }^{8}$ Student Survey of the Nordic Master Programme 2012. Oxford Research, August 2012.

http://www. norden.org/da/publikationer/publikationer/2013-903

${ }^{9}$ Interviews with students on the Nordic Master Programme. Nordic Council of Ministers' Secretariat, project coordinator Anniina Pirttimaa, September 2012.

http://www. norden.org/da/publikationer/publikationer/2013-901
} 


\section{The general views of the committee}

The Nordic Master Working Committee is in favour of continuing the programme. The pilot phase has been largely positive, even though not all of the initial objectives have been met. The pilot project has encouraged HE institutions to work together and some consortia have also developed new models for collaboration. Some programmes have generated new academic content, while others have offered new opportunities to combine existing courses. In the online questionnaire in 2012, students expressed widespread satisfaction with the Nordic mobility aspect of the programme ( $73 \%$ very satisfied, $17 \%$ satisfied) and with the academic content ( $54 \%$ very satisfied, $41 \%$ satisfied). This was confirmed by the qualitative interviews, in which students described the NMP as a unique opportunity with great potential.

The committee concurs with the conclusion of the 2010 evaluation that a future NMP will require joint development work on many different levels and involving many different stakeholders. Continuation of the programme will require a decision at ministerial level if the ongoing funding is to be guaranteed. The legal challenges faced cannot be solved immediately - overcoming them will require the willingness to do so as well as long-term work at national level, e.g. on accreditation, forms of examination and diplomas, study fees and barriers to cross-border mobility. Although the primary responsibility for work to abolish obstacles to freedom of movement lies with the ministers, the various government agencies responsible for legislation also need to be involved. The Nordic Council of Ministers and co-operation between Nordic universities and colleges in general have important roles to play in co-ordinating the political and legal development work.

The student survey identified a number of practical problems to do with the way the programmes are run, e.g. inadequate information about marketing and recruitment, the structure of the programmes not being logical and transparent, and the fact that it is not always possible to compare ECTS credits between programmes. These are mainly challenges for the institutions. If a programme like NMP is to succeed, commitment is required at all levels - from university management to the academic staff and administrative personnel.

The national educational authorities and institutions cannot deal with some of the biggest challenges on their own, e.g. visa rules or a lack of housing. In such cases, it is important to identify the cause of the problem and work towards lasting solutions. At programme level, it is particularly important to inform students of potential problems at the earliest possible stage.

\section{PROPOSAL:}

1. Make the Nordic Master Programme permanent and earmark funding from the Nordic budget. 


\section{The NMP - purpose and Nordic added value}

The committee sees the NMP as a means with which to internationalise Nordic HE and enhance the visibility of the Region around the world. The programmes provide the opportunity to instil a greater international element into teaching at domestic level. Many of the Nordic students commented on this in the survey - they had not necessarily had the opportunity or interest in travelling abroad on student-exchange programmes elsewhere in Europe, but were now able to do so within the Region. Contacts forged during student years often form the basis for an international network that lasts well into the future. The research contacts made by NMP students also represent valuable future assets, regardless of whether they embark on a career in research or work on something else.

Another dimension of globalisation is that motivated and talented students from outside of the Region are attracted by the opportunity to study in more than one Nordic country. Most NMP courses are taught through the medium of English, which makes the programme even more attractive to non-Nordic students - who have criticised cases where not all courses were offered in English. At the same time, however, they have also been motivated to learn the local languages as part of their Master's studies. Several non-Nordic students also clearly stated that they would like to be integrated into the local culture, and up to $82 \%$ of all students said that they would like to stay in the Region. The majority of those interviewed also said that they wanted to look for jobs in the Region after graduation.

The committee notes that the international public is relatively unaware of the Master's level of education, even though it has evolved greatly and has received a major boost from the Bologna Process. With this in mind, a high-quality NMP with research-based teaching and direct links with the research community would help develop the whole Master's level into an even more solid foundation for further studies. It would also be natural to link the NMP with existing or emerging centres of excellence in the Region, e.g. the Top-level Research I nitiative. A majority of respondents to the student questionnaire $(61 \%)$ said that they would be interested in a graduate programme at some point in the future.

The committee does not think that strong research links preclude strong links to the labour market. The days are gone when graduate programmes were seen as only leading to a research career in academia. Business and industry need experts with experience in and knowledge of research. The student survey and workshops revealed a strong desire for links to both worlds - of research and of work.

The committee also emphasises that excellence should be defined broadly and that in this case it should be considered as synonymous with high quality - in terms of the academic content, teaching and the way in which the programmes are run. Excellence can also mean nurturing and developing small academic areas through Nordic co-operation. If we want to instil excellence as early as the funding-application phase, consortia must identify and be able to refer to the Nordic added value provided by the proposed NMP. The Council of Ministers must not fund activities that are part of the institutions' normal, everyday work.

\section{PROPOSALS:}

2. Make the main purpose of the NMP to internationalise Nordic HE.

3. Base the NMP on excellence and insist on high quality and systematic quality assurance.

4. Make sure that all NMP programmes are research-based with links to the worlds of research and work. 


\section{Framework and management}

The committee discussed three options for the future structure and running of the NMP: management by independent administrators, by Nordforsk or by Nordplus.

\section{Independent administrator}

The first NMP call to tender in 2007 was processed by the Council of Ministers' Secretariat (NMRS) in Copenhagen. The Norwegian Centre for International Co-operation in Education (SIU) has been responsible for the three subsequent calls. SIU is a national agency that takes on a variety of Nordic and international tasks. Running the programme in this way, with an external administrator, is a viable option for the future but it is not without its challenges, e.g. in relation to guaranteeing continuity, establishing links with centres of excellence and other relevant themes. Another challenge is to guarantee parity between the countries involved when the programme is run by a national organisation not originally set up with a pan-Nordic function. The 2010 evaluation called for stronger Nordic roots for the management of the NMP as well as stronger Nordic branding. ${ }^{10}$

\section{Nordplus}

Nordplus has existed since 1988 and is now a Nordic-Baltic programme. It consists of five subprogrammes: Junior, Higher Education, Adult, Horizontal and Nordic Languages. Nordplus Higher Education must, naturally, be taken into account when discussing options for the future of the NMP. On occasion, the content of Nordplus Horizontal may also correspond to parts of the NMP.

Nordplus Higher Education funds the following types of activities:

$>$ Mobility for students and teachers

$>$ The building and development of networks

> Project activities - courses, joint study programmes, development projects.

Until now, the NMP and Nordplus have been able to provide support to similar activities - joint study programmes that lead to a qualification. NMP funding is, however, usually on a larger scale. Nordplus also provides support to programmes that do not lead to a joint/dual degree (e.g. programme modules) and also provides support for programmes at Bachelor level.

The consortia that have received NMP funding have been eligible to apply for mobility scholarships from Nordplus and many have done so successfully. In fact, some NMP consortia name Nordplus mobility scholarships as a prerequisite for implementing their programmes, especially for intensive courses where the entire NMP group meets for one or several shorter periods of time. The NMP itself has not directly funded any form of student mobility, and almost all of the programmes have mentioned this as a major shortcoming. The exact number of NMP students who have received Nordplus mobility funding is difficult to calculate. It is institutions that apply for mobility funding - the applications do not necessarily mention that they are for NMP students.

The Nordplus experts think it is untenable to expect Nordplus to fund NMP mobility systematically in the long term. It is impossible to prioritise NMP applications because competition for funding is already fierce. In future, the two programmes should have clearer profiles. One possible alternative would be for Nordplus to act as a Nordic-Baltic programme, which provides funds for positive and creative ideas and for building networks in the initial phase. Some of these ideas could later be developed into NMP programmes. The NMP should have closer links to existing or upcoming Nordic centres of excellence and be of high and recognised quality. This would endow both programmes with more distinct profiles of their

\footnotetext{
10 Student Survey of the Nordic Master Programme 2012. Oxford Research, August 2012. http://www. norden.org/da/publikationer/publikationer/2013-903
} 
own.

\section{NordForsk}

NordForsk was established on 1 January 2005 as an independent Nordic institution under the Nordic Council of Ministers for Education and Research (MR-U). Its main responsibility was to promote effective co-operation between the Nordic countries in promoting research and graduate training of the highest international quality. The establishment of NordForsk was part of the reform of co-operation in research and innovation that occurred in the middle of the last decade, a reform that resulted, for instance, in the establishment of the Nordic Research and Innovation Area (NORIA).

In 2011, NordForsk entered its second strategic period (2011-2014), and its activities now focus on five main priorities: a) co-operation on research infrastructures, b) funding of Nordic research co-operation, c) research co-operation between the Nordic Region and the EU, d) analysis and policy activities and e) communicating and publicising the results of Nordic research co-operation.

Until now, the NMP has not had any relation to NordForsk. Many of the programmes have, however, had the same thematic approach as those that NordForsk calls its Nordic Centres of Excellence, e.g. climate research. The committee proposes to examine the possibility of linking the NMP and NordForsk more closely together. NordForsk should be able to offer the NMP a strong pan-Nordic environment with high academic quality. The interaction between them should serve as a good opportunity to develop research-based NMP programmes.

If the "Nordic Master" is to develop into a high-quality educational brand, it should be viewed as a single programme and not as a large number of initiatives or separate programmes. The NMP also needs a permanent "home", with an administrator capable of developing the programme in the longer term. NordForsk is already a Nordic brand, and this might help the marketing and profiling of the "Nordic Master" brand. Together, the NMRS and NordForsk should be able to come up with a model for the management and development of the programme. To do so, the division of responsibilities between the NMRS, NordForsk and the consortia that run the individual programmes would need to be clarified.

The committee and the management of NordForsk have discussed the option of formally linking the NMP to the NordForsk organisation. Nordforsk thinks the best way to do this would be within the framework of its research activities, e.g. the Nordic Centre of Excellence (NCoE) programme. The NCoE consists of major theme-based investments, e.g. in eScience, educational research and the climate. According to Nordforsk, the best way to draw up the framework conditions for the NMP and implement the programme would be within a process connected with the development of each individual NCOE or within the frameworks of other relevant NordForsk activities. NordForsk also thinks that if the NMP was based on themes (in the same way as the rest of NordForsk's activities) and developed within the framework of other relevant NordForsk activities, then the best way to achieve synergies would be to use the existing Nordic research collaboration as the basis for the development of NMP programmes.

\section{Conclusions}

The committee thinks that NordForsk would be the best choice as the future administrator of the NMP. This would provide opportunities to make HE even more research-based and to develop internationally attractive NMP degrees. NordForsk is already a Nordic organisation. As well as its strong focus on excellence in research, it also offers experience of calls for tender and administrative processes at Nordic level. The committee believes, however, that the future NMP should not only be limited to the topics covered by NordForsk's own Top-level Research Initiative or other politically motivated themes. Restricting the NMP to predetermined themes would entail running the risk of missing out on involvement in important new emerging 
academic areas.

Another potential solution for the NMP would be an independent administrator, as has been the case for the last three calls to tender. However, this would not automatically generate the same synergy with Nordic themes, excellence or Nordic policy. Nor would an independent organisation necessarily have the experience in quality assurance, marketing and profiling of a Nordic brand.

Nordplus is now a Nordic-Baltic programme and has a broader base than the NMP. The committee does not see it as the most relevant administrator for the NMP. However, it will be important to develop Nordplus Higher Education and the NMP in such a way that the programmes complement each other, rather than competing with or overlapping each other.

\section{PROPOSALS:}

5. Examine the possibility of linking the NMP and Nordforsk more closely together.

6. Consider the potential of linking the NMP to NordForsk's big, strategically important research initiatives, yet without restricting the NMP only to NordForsk's areas of excellence.

7. Clarify the relationship between Nordplus and the NMP and profile the programmes so that they complement each other. 


\section{Funding}

During the pilot project, the Council of Ministers has only provided funding for the planning phase of each programme. Each programme received DKK 1 million and, in most cases, the money was spent on planning during the first year after the decision to approve the programme. This approach has been criticised by the programme co-ordinators, universities and students. On the one hand, the amount is sometimes considered too much just for planning activities. On the other hand, funding for student mobility and co-ordination work once the programmes are underway has been in short supply. Students have expressed serious concerns about the lack of both co-ordination and a designated contact person throughout the programme cycle. As mentioned above, since 2007 most programmes have managed to source additional funding for mobility from either Nordplus or a similar source.

The committee would like to see more wide-ranging criteria for the use of NMP funds. In future, consortia should be accorded relative freedom and the right to deploy funds according to actual needs, including planning, operations and mobility. A maximum of DKK 1.5 million should be reserved per programme, with the stipulation that the funds be used within a period of five years after the decision to proceed with the programme. At least three programmes should be funded per annum. A certain amount of money also needs to be earmarked annually for the joint Nordic management of the programme. In addition to Nordic funds and standard institutional funding for teaching, participating educational institutions should also continue to be expected to contribute to the funding of the co-ordination and of ongoing development work and operations after the initial five-year period. This will guarantee greater sustainability and continuity.

Another financial challenge concerns the different rules and traditions for tuition fees for nonEU/EEA students in the Nordic countries. Differences in regulatory frameworks impede cooperation and confuse students as they try to navigate the system. An example has been recorded of a student having to pay parallel fees to two universities on the grounds that the student concerned was resident in two different countries. The situation regarding tuition fees has also not always been clear and has sometimes come as a surprise to students after they had already started their studies. It is difficult to provide students with precise information about this because the situation is dynamic - e.g. Finland is running a pilot project until 2014. In consortia with decentralised recruitment, a clear tendency to apply via an institution in Norway, where tuition fees are not charged, has emerged. The number of students who have found fees a major issue has, however, been relatively low so far - the biggest financial challenge is posed by the high cost of living in the Nordic Region. On the other hand, it is possible to predict that study fees will become a more severe problem if the total number of students grows and if the marketing targets non-European countries to an even greater extent.

The working committee does not envisage tuition fees being an obstacle to non-European students opting for the NMP. If it is not possible to waive fees for non-European students then the problem will have to be solved by systematically offering scholarships to them. This can be justified on the grounds that the total number of programmes and students is relatively small. If the programme is to be seen as a high-quality programme of excellence, then the students also have to be seen as a future resource and an investment for the Nordic countries. It is important to consider the non-European students' finances during the study period as a whole - tuition fees, scholarships, visas and other start-up costs should all be taken into account. The committee unanimously agrees, however, that the Council of Ministers should not fund tuition fees. 


\section{PROPOSALS:}

8. Extend the criteria for deploying NMRS funds so that, as well as the planning period, funding also covers part of the operational costs of the programme and student mobility.

9. Solve the problem of tuition fees by waiving fees for all NMP students or by developing a scholarship scheme for non-European students.

10. Earmark a total of at least DKK 4.5 million plus an administration fee annually for the NMP from the joint Nordic budget.

11. Fund at least three programmes per annum.

12. Consortia must invest a sum of money in the joint co-ordination of the programme once it is up and running. 


\section{Legal and administrative challenges}

The above-mentioned problem of tuition fees is not the only legal and administrative challenge faced by the NMP. Another major challenge has been the differences in the regulatory frameworks as far as dual or joint degrees and diploma supplements are concerned. The different countries operate with different definitions and different names for qualifications. This issue has mainly been raised by the co-ordinators but students have mentioned it too. The biggest problem is that it has not always been made clear to the students what kind of certificate they will receive. This generates uncertainty about the quality of the programme. In some cases, students have not received their certificates until a year after graduation because the consortium was unable to agree on the form it should take. The fact that they vary widely is also a quality factor - if a distinct brand is the objective, then a common model for the certificate would be preferable.

Accreditation means that the study programme is reviewed, analysed, accepted or rejected by a committee or a group of experts appointed for the task. The countries have different traditions and rules for accreditation. In Finland, the word accreditation is not used. The Finns talk instead about recognition of study programmes. In Norway, the word recognition specifically refers to studies completed in a later phase of an individual's professional life.

However, it seems as if the consortia have been able to find pragmatic solutions to joint/dual degrees as long as the programmes have been accredited. The working committee thinks that universities and colleges should ensure that NMP programmes are fully accredited in all of the participating countries before commencing student recruitment. This is particularly important if university colleges or vocational colleges participate in the consortium, because credits are not automatically transferred between universities and professional/vocational colleges, either at a national or Nordic level.

The working committee proposes that an expert group be set up, tasked with drawing up a common definition and model for the certificates that are awarded under the NMP. A European working group has been charged with drawing up similar recommendations for joint/dual degrees and is expected to finalise its work during $2013^{11}$. It is important that the proposed Nordic expert group relates to the European framework of reference.

Recruiting students has been particularly difficult for small specialist subjects. Semester structures, study credits, different quality requirements, differences in curricula, cultural differences, etc. have all proved to be minor problems to which solutions have usually been found within the consortium. These will be discussed in greater detail when drawing up guidelines for the management of programmes and support materials for administrators.

\section{PROPOSALS:}

13. Accreditation of NMP programmes to be in place in all participating countries before student recruitment commences.

14. Harmonise the accreditation process so that the accreditation of an NMP programme in one country leads to automatic accreditation in the other Nordic countries.

15. Enlist the help of experts to draw up recommendations for joint forms of examination and certificates.

\footnotetext{
${ }^{11}$ http://www.ecaconsortium.net/main/projects/jogar
} 


\section{Profile and marketing}

\section{"Simply put, a brand is a promise. By identifying and authenticating a product or service it delivers a pledge of satisfaction and quality." (Walter Landor)}

According to Landor's reasoning, a brand consists of knowledge, opinions, emotions, myths, rumours, and experiences in the mind of the purchaser or consumer - in other words, it does not consist of direct properties of the product. It is a mental association that instinctively tells the purchaser what to expect from the brand. To turn the NMP into a well-known brand will call for consistent and deliberate work on the concept on many different levels. The brand, quality assurance and marketing are closely interconnected and should be developed at the same time.

Profiling the brand requires that the basic purpose of the programme is clear, that the programme constitutes a holistic unit and that it has its own management organisation. The Nordic added value is what differentiates NMP programmes from other types of Master's, especially now that it is common for the medium of instruction to be English even on national Master's programmes.

The quality and design of NMP programmes varies greatly in the current pilot project. Allowing for this variation during the start-up phase was a conscious choice by the Council of Ministers, and it has encouraged new and creative outcomes. However, it has also caused problems when it comes to profiling the NMP brand. A clear and visible brand requires standards and restrictions. For example, the mobility element needs to be better defined. It currently varies from a few weeks to several months spent in other Nordic countries.

Part of profiling is to relate the NMP to other corresponding mobility programmes. Nordplus has already been mentioned above, but another relevant programme is Erasmus Mundus. It currently provides support for the following: student mobility, staff mobility, intensive programmes, intensive language courses and collaborative projects between universities. Erasmus Mundus will have a new name at the beginning of 2014 and will be significantly better funded than currently. It is still somewhat unclear what the new ERASMUS will look like.

Currently, there is no relationship between Erasmus Mundus and the NMP and they are not directly comparable - Erasmus Mundus is much bigger. The variety of activities funded by Erasmus is also much greater, and the NMP only supports joint programmes at Master's level. The biggest practical difference between Erasmus Mundus and the NMP is that the Erasmus Mundus programme provides mobility grants for students. This was also mentioned as a competitive factor in favour of Erasmus Mundus by some students in the qualitative interviews conducted as part of the NMP student survey.

A brand is always linked with marketing. Many students expressed their dissatisfaction with the visibility and marketing of the current NMP. The Council of Ministers has political and financial responsibility for the programme, and it would be logical for the NMRS to have joint responsibility for the marketing. Who does what, e.g. with regard to websites and other information, should be clarified between the NMRS, the proposed administrators and the consortia. As mentioned above, marketing could deliberately target parts of the world where the Region or the individual Nordic countries are already well known.

The original objective of raising the visibility of the NMP and, thus, education in the Nordic Region has not been achieved in a satisfactory manner. This emerges both from the 2010 evaluation and the 2012 student survey. It may be due to the fact that the NMP is still new, and that the programmes are relatively few. Another reason may be that the programmes have been allowed to work relatively independently to date without major centralised support 
and co-marketing by the Nordic Council of Ministers or the administrator. Students think that the marketing of the programme could be improved, e.g. with better websites and media visibility. Targeted recruitment campaigns have not been run. It is, therefore, gratifying that non-European students have still managed to discover the programme. Of the 91 students who responded in 2012, 42\% were from the Nordic Region, 39\% were non-Europeans and $19 \%$ Europeans, which mirrors the proportions among all NMP students. The committee notes that academic contacts and networks between the Region and China, the United States, Canada, the Baltic States and Russia, have already been established. It would be logical also to make use of these in the marketing of the NMP. The programmes could also be marketed in the Nordic countries to a greater extent.

The student survey shows that students have a strong need to identify with the NMP. Most programmes have failed to offer sufficient Nordic mobility and interaction, and individual students criticise their programmes for having a minimal "Nordic dimension". There is a need to set some sort of minimum requirements for the extent of the mobility in the programmes. Universities also need to invest in providing a reasonable level of social activities during the studies. NMP alumni seem to be highly motivated to participate in the follow-up and development of NMP. Students could also be deliberately included in the marketing of the programme.

By linking to NordForsk, the NMP could also take advantage of NordForsk's existing networks and structures for marketing and profiling of the brand. NordForsk is known outside the Nordic Region, and should therefore be able to help make the NMP visible as a high-quality programme with a strong research base.

\section{PROPOSALS:}

16. Strive professionally to make NMP a strong brand.

17. Profile the NMP so that it brings to the table something that is not offered by Erasmus Mundus or similar mobility programmes, and has a clear and distinct Nordic profile.

18. Use existing networks and contacts to promote the NMP.

19. Invest further in targeted marketing of the NMP and define the target groups better.

20 . Include students in the profiling of the brand and in quality assurance. 


\section{Quality assurance and practical guidelines}

It has already been ascertained that the quality and design of the programmes varies greatly in the current pilot project. This has led to problems, e.g. for the brand. The committee is of the opinion that a quality-assurance system should be drawn up for the NMP. This should take into account the work already carried out by the Nordic Quality Assurance Network in Higher Education (NOQA) (J oint Masters Programmes - J oint Evaluations, 2009).

Erasmus Mundus has struggled to assure the quality of its programmes, e.g. not all credits are accepted by home universities. J oint and dual degrees are a problem both on the European and on the Nordic level. The EU Presidency seminar in Copenhagen, May 2012, concluded that, henceforth, quality rather than quantity should be the priority for Erasmus Mundus. Evaluations and student surveys clearly show that quality assurance is also one of the greatest challenges currently facing the NMP.

Practical problems - the cost of living, housing, visa requirements, etc. - were brought up relatively frequently during the student survey. They constitute bigger challenges for nonEuropean students and are difficult to solve within the frameworks of the NMP. According to the student survey, however, these are very important issues for individual students and may present insurmountable obstacles. In the worst cases, such factors can undermine the students' perceptions of the quality of the programme, even if the academic quality is high. Work must continue on these problems at both official and policy level, but it is particularly important that they are addressed when drawing up support materials for the programme coordinators. This will allow the institutions to look into them and inform applicants in good time.

To assure quality right from the application stage, the following factors must be taken into account:

- All parties must commit to the partnership at different levels: the academic staff, administrative personnel and the management of the institution

Nordic added value

Sustainability

Academic quality and study outcomes

Mobility

Internationalisation

Support functions

Induction - guidance and information, accommodation

Scholarships

Forms of exams and certificates

Accreditation of the programme in all of the countries in the consortium

Budget up to five years.

It emerged clearly from discussions with both the programme co-ordinators and the students that support materials and guidelines are needed to build up a homogenous, high-quality NMP. The guidelines will take the form of a handbook. In the autumn of 2012, the NMRS and NMP coordinators drew up a preliminary table of contents for such a handbook (see Appendix 2).

\section{PROPOSALS:}

21. Build up a quality-assurance system for the NMP based on the existing quality work in the HE sector in the Nordic Region.

22. Develop clear criteria for the implementation of programmes as early as the application phase.

23. Develop materials to support future programmes and administrators. 


\section{The proposals in brief}

\section{The general views of the committee}

1. Make the Nordic Master Programme permanent and earmark funding from the Nordic budget.

\section{The NMP - purpose and Nordic added value}

2. Make the main purpose of the NMP to internationalise Nordic HE.

3. Base the NMP on excellence and insist on high-quality and systematic quality assurance.

4. Make sure that all NMP programmes are research-based with links to the worlds of research and work.

\section{Structure and management}

5. Examine the possibility of linking the NMP and Nordforsk more closely together.

6. Consider the potential of linking the NMP to NordForsk's big, strategically important research initiatives, without restricting the NMP to NordForsk's areas of excellence.

7. Clarify the relationship between Nordplus and the NMP and profile the programmes so that they complement each other.

\section{Funding}

8. Extend the criteria for deploying NMRS funds so that, as well as the planning period, funding also covers part of the operational costs of the programme and student mobility.

9. Solve the problem of tuition fees by waiving fees for all NMP students or by developing a scholarship scheme for non-Nordic students.

10. Earmark a total of at least DKK 4.5 million plus an administration fee annually for the NMP from the joint Nordic budget.

11 . Fund at least three programmes per annum.

12. Consortia must invest a sum of money in the joint co-ordination of the programme once it is up and running.

\section{Legal and administrative challenges}

13. Accreditation of NMP programmes to be in place in all participating countries before student recruitment commences.

14. Harmonise the accreditation process so that the accreditation of an NMP programme in one country leads to automatic accreditation in the other Nordic countries.

15. Enlist the help of experts to draw up recommendations for joint forms of examination and certificates.

\section{Profile and marketing}

16. Strive professionally to make NMP a strong brand.

17. Profile the NMP so that the programme offers something more than Erasmus Mundus or similar mobility programmes and has a clear and distinct Nordic profile.

18. Use existing networks and contacts to promote the NMP.

19. Invest further in targeted marketing of the NMP and define the target groups better. 
20. Include students in the profiling of the brand and in quality assurance.

\section{Quality assurance and practical guidelines}

21. Build up a quality-assurance system for the NMP based on the existing quality work in the HE sector in the Nordic Region.

22. Develop clear criteria for the implementation of programmes as early as the application phase.

23. Develop materials to support future programmes and administrators. 


\section{Appendix 1: Nordic Master programmes}

\section{7}

Nordic Master in Gerontology (NordMaG)

- University of Jyväskylä (FI), coordinator

- University of I celand (IS)

- Lund University (SE)

Nordic Master in Plant Pathology (NorPath)

- Swedish University of Agricultural Sciences (SE), coordinator

- University of Copenhagen (DK)

- University of Helsinki (FI)

- Agricultural University of I celand (IS)

- Norwegian University of Life Sciences (NO)

Nordic Master in the Religious Roots of Europe

- Aarhus University (DK), coordinator

- University of Bergen (NO)

- University of Copenhagen (DK)

- University of Helsinki (FI)

- Lund University (SE)

- University of Oslo (NO)

Nordic Master in Marine Ecosystems and Climate

- University of Bergen (NO), coordinator

- University of I celand (IS)

- University of Faroe Islands (FO)

Nordic Master in Innovative Sustainable Energy Engineering

- KTH Royal Institute of Technology (SE), coordinator

- Aalto University (FI)

- Technical University of Denmark (DK)

- Norwegian University of Science and Technology (NO)

- Chalmers University of Technology (SE)

- University of I celand (IS)

Nordic Master in Innovative Information and Communication Technologies (ilCT)

- University of Turku (FI), coordinator

- Technical University of Denmark (DK)

- KTH Royal Institute of Technology (SE)

- Åbo Akademi University (FI)

\section{9}

Nordic Master in Computational Chemistry and Physics

- University of Tromsø (NO), coordinator

- Göteborg University (SE)

- University of I celand (IS)

- Helsinki University (FI)

- KTH Royal Institute of Technology (SE)

Nordic Master in Maritime Engineering

- Technical University of Denmark (DK), coordinator 
- Aalto University (FI)

- Chalmers University of Technology (SE)

- KTH Royal Institute of Technology (SE)

- Norwegian University of Science and Technology (NO)

- Technical University of Denmark (DK)

Nordic Master in Didactics of Mathematic

- University of Agder (NO), coordinator

- Åbo Akademi University (FI)

- University of Tampere (FI)

- Danish School of Education (DK)

Nordic Master in Everyday Practices in Changing Societies (programme cancelled)

- Helsinki University ( FI), coordinator

- Linköping University (SE)

- Roskilde University (DK)

- University of Stavanger (NO)

\section{0}

Nordic Master in Viking and Medieval Norse Studies

- University of I celand (IS), coordinator

- Aarhus University (DK)

- University of Oslo (NO)

- The Árni Magnússon Institute for Icelandic Studies (IS)

- University of Copenhagen (DK)

Nordic Master in Aquatic Food Production-Safety and Quality (AQFood)

- Technical University of Denmark (DK), coordinator

- Norwegian University of Science and Technology (NO)

- University of I celand (IS)

- Swedish University of Agricultural Sciences (SE)

- Norwegian University of Life Sciences (FI)

Nordic Master in Dance Education as Artistic Practice and Research (programme cancelled)

- Theatre Academy (FI), coordinator

- University of Dance and Circus (SE)

- University of Copenhagen (DK)

Nordic Master in Environmental Engineering (eNviro5Tech)

- Technical University of Denmark (DK), coordinator

- Aalto University (FI)

- Norwegian University of Science and Technology (NO)

- Chalmers University of Technology (SE)

- KTH Royal Institute of Technology (SE)

Nordic Master in Sustainable Urban Transitions

- Chalmers University of Technology (SE), coordinator

- Aalto University (FI)

- Norwegian University of Science and Technology (NO)

- KTH Royal Institute of Technology (SE)

Nordic Master in Biodiversity and Systematics

- Göteborg University (SE), coordinator

- Lund University (SE)

- Stockholm University (SE) 
- Uppsala University (SE)

- Aarhus University (DK)

- University of Copenhagen (DK)

- University of Bergen (NO)

- University of Oslo (NO)

- University of Tromsø (NO)

\section{2}

Nordic Master in Vision Rehabilitation

- Buskerud University College (NO), coordinator

- University of Copenhagen (DK)

- Göteborg University (SE)

- Instituttet for Blinde og Svagsynede, Copenhagen (DK)

- Kennedycentret, Glostrup (DK)

- Huseby Kompetansesenter (NO)

Nordic Master in Polymer Technology

- KTH Royal Institute of Technology (SE), coordinator

- Technical University of Denmark (DK)

- Aalto University (FI)

- Chalmers University of Technology (SE)

- Norwegian University of Science and Technology (NO)

Nordic Master in Managing Societal Development in the High North (DEV4NORA)

- University of I celand (IS), coordinator

- Greenland University (GL)

- University of Nordland (NO)

- Akueiry University (IS)

- University of the Faroe I slands (FO)

- The Árni Magnússon Institute for I celandic Studies (IS)

Nordic Mining School

- Luleå University of Technology (SE)

- Technical University of Denmark (DK)

- Mineskolen i Sisimut, DTU-Artek (GL)

- Oulu university (FI)

- Norwegian University of Science and Technology (NO)

- University of Tromsø (NO)

- University of I celand (IS) 


\section{Appendix 2: Draft guidelines for future Nordic Master programmes}

\section{Content}

1. Introduction

2. Designing the NMP

i. Commitment to the NMP

i. Ensuring commitment on all levels

ii. Formal contract between the partners

1. Example contract

ii. Financing the NMP
i. Support from NCM
ii. Own investment
iii. Tuition fees

iii. Nordic added value

iv. Academic content and quality

i. Entry requirements

ii. Accreditation

iii. Study plan

1. Options within the NMP

iv. Course structure

1. Special NMP courses vs. regular curriculum

2. Contact seminars

3. Online courses

4. Including work/research experience

v. Course and grade compatibility

1. Learning outcomes

vi. Type of degree

1. Granting of the degree

v. Mobility

i. Purpose of mobility

ii. Extent of mobility

iii. Mobility grants to students

vi. Including administrative personnel

i. Ensuring compatibility

1. Application timeframe

2. Acceptance to the programme

3. Including courses in administrative systems

4. Compiling and sending diplomas

3. Co-ordination

i. Need for academic and administrative co-ordination

ii. Organisational structure

i. Main NMP co-ordinator

1. Ensuring overall co-ordination

a. Focus on academic content, but close co-operation with administrative staff on administrative matters

2. Financing a common co-ordinator

ii. Local NMP co-ordinators 
1. Clear contact point for local students

a. Focus on academic guidance, but close co-operation with administrative staff on administrative matters

iii. Steering mechanism

1. Including the students

4. Marketing

i. Defining target group

i. Within the Nordic countries

ii. Outside the Nordic countries

ii. Defining methods and timeframe

i. Website

ii. Other marketing material

a. Utilising existing networks

5. Support functions

i. Clear information on the NMP

i. During application

ii. After acceptance

ii. Accommodation

i. Support in finding accommodation

iii. Welcome programme

i. Creating a NMP group feeling

1. Support of earlier NMP students

ii. Introduction to local campus

iii. Contact to local student life and culture

iv. Other student services

iv. Academic guidance

i. Early introduction to options within NMP

ii. Support in designing the NMP

iii. Continuous academic guidance throughout the programme

6. Life after the NMP

i. Contacts to industry/working life

ii. Information on PhD options

iii. Maintaining a NMP alumni network 


\section{Background material}

Nordic Master Programme - Legal, financial, institutional and practical barriers. Nordic Institute for Studies in Innovation, Research and Education (NIFU). Agnete Vabø, Synnøve Skjersli Brandt, Per Olaf Aamodt. NIFU Rapport 40/2012, Oslo, Norway. http://www. norden.org/da/publikationer/publikationer/2013-908

Tuition fees for international students - Nordic practice. Oxford Research, December 2012 http://www. norden.org/en/publications/publikationer/2013-516

Evaluation of Nordic Master Programme (in Danish). Oxford Research, January 2010.

http://www.norden.org/da/nordisk-ministerraad/ministerraad/nordisk-ministerraad-for-uddannelse-ogforskning-mr-u/raadgivningsgrupper/raadgivningsgruppen-for-nordisk-samarbejde-inden-for-hoejereuddannelse-hoegut/nordic-master-program/evaluering-af-nordic-master-programme/

Student Survey of the Nordic Master Programme 2012. Oxford Research, August 2012. http://www.norden.org/da/publikationer/publikationer/2013-903

Interviews with students on the Nordic Master Programme. Nordic Council of Ministers' Secretariat, project co-ordinator Anniina Pirttimaa, September 2012

http://www.norden.org/da/publikationer/publikationer/2013-901 